\title{
Seasonal Dynamics of Forage Shrub Nutrients
}

\section{By Kelly L. Memmott, Val Jo Anderson, and Rachel Fugal}

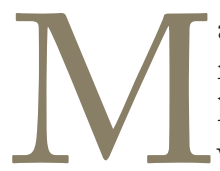

any shrubs that thrive in the intermountain region of the western United States retain high nutrient concentrations throughout the winter. The presence of these shrubs on livestock winter ranges can reduce or even eliminate the need for supplemental feed. The additional nutrients available in the shrubs can also improve the winter nutritional status of wildlife, especially big game.

\section{History}

Many native rangelands in this region were originally composed of mixtures of grasses, shrubs, and forbs. This native vegetation was not subjected to the pressures of grazing for thousands of years prior to European settlement and so did not build tolerances for it. While the Great Plains supported the vast herds of bison, grazers in the Intermountain West consisted of small herds of bighorn sheep, antelope, deer, and elk in quantities that made it difficult in some areas for the early settlers to obtain sufficient food., ${ }^{1,2}$ Subsequently, disturbances such as overgrazing and fire suppression combined with frequent droughts typical of the desert climate have prevented the recovery of these grasses and led to the domination of many rangelands by shrubs (particularly big sagebrush) and invasive annual species. ${ }^{3}$

To return these rangelands to a condition more suitable for livestock production, crested wheatgrass, a grazingtolerant and fire-resistant perennial grass introduced from Asia, has commonly been seeded. More than 6-11 million ha (14.8-27.2 million acres) have been seeded to crested wheatgrass in the western United States, often as monocultures. ${ }^{4,5}$ This now-abundant grass provides a balanced nutritional base for cattle when it is actively growing. However, as the grass goes dormant, its nutritional quality declines dramatically. Although they provide adequate energy, dry grass culms do not furnish sufficient nutrients to sustain most grazers without supplements.

\section{Purpose}

Shrubs interplanted with grasses can provide the needed supplement of essential nutrients, especially protein, as the grasses dry. Such a combination of grasses and shrubs can prolong the grazing season of seeded pastures. In this study, we monitored the seasonal dynamics of the nutrient concentrations found in several shrub species relative to crested wheatgrass in shrub/grass mixed pastures.

\section{Study Area Near Malta, Idaho}

We conducted this research adjacent to Brigham Young University (BYU) Skaggs Research Ranch located approximately $14.4 \mathrm{~km}$ (8.9 miles) north of Malta, Idaho at an elevation of 1,342 $\mathrm{m}$ (4,403 feet). Typical of the cold desert ecosystem of south-central Idaho, the landscape is characterized by low-lying valleys bordered with mountain ranges running north and south. A sagebrush-grass mix dominates the vegetation on a silt loam soil with a basic $\mathrm{pH}$ greater than eight throughout the profile. ${ }^{6}$ Cold, dry winters and hot summers, with most precipitation falling as rain or snow in spring and late fall, are typical in this area. Average annual precipitation is $22.8 \mathrm{~cm}$ (9.0 inches) and average daily temperatures range from $-2^{\circ} \mathrm{C}\left(28^{\circ} \mathrm{F}\right)$ in January to $18.5^{\circ} \mathrm{C}\left(65^{\circ} \mathrm{F}\right)$ in July.

Brigham Young University, in cooperation with the USDA Forest Service Shrub Science Laboratory, leased the study area from the J. R. Simplot Company in 1985 for a period of 10 years. This area, with a history of spring and fall grazing for several years prior to $1985,{ }^{6}$ had plant cover consisting of a seeded stand of crested wheatgrass (Agropyron cristatum [Fisch. ex Link] Schult.) intermixed with Wyoming big sagebrush (Artemisia tridentata Nutt. ssp. wyomingensis Beetle and Young).

\section{Planting Procedures}

Beginning in the fall of 1985, students and researchers from BYU and the Shrub Sciences Laboratory prepared the 20-ha (49.4-acres) study site with an aerial spraying of 2,4-D (2,4-dicholorophenoxy acetic acid), a broad-leaf selective herbicide, to remove all existing shrub species. In 1986, they tilled 1-m (3.3-feet) wide strips with a rear-mount tractor-powered tiller to a depth of $20 \mathrm{~cm}$ (7.9 inches) at $2.5-\mathrm{m}$ (8.2-feet) intervals. In 1987, they subdivided the area into five, 4-ha (9.9-acres) parcels and transplanted shrub seedlings, of a single species per parcel, at $1.5-\mathrm{m}$ (4.9-feet) intervals into the tilled strips of each parcel. The five shrub species transplanted were Wyoming big sagebrush, fourwing 
saltbush (Atriplex canescens [Pursh.] Nutt.), prostrate kochia (Bassia prostrata [L.] A. J. Scott), rubber rabbitbrush (Ericameria nauseosa [Pall. ex Pursh] G. L. Nesom \& Baird ssp. nauseosa var. nauseosa), and winterfat (Krascheninnikovia lanata [Pursh.] Meeuse and Smit). They established exclosures of 0.04 ha $(0.09$ acres $)$ within each pasture which continuously kept them free of grazing. ${ }^{7}$

\section{Nutrient Concentration Monitoring}

Eight years after transplanting, we began monitoring nutrient concentrations in the grass/shrub matrices from the beginning of shoot development in May 1993 until snowfall in December 1993. We removed 10-g (0.35-ounce) samples of the current year's growth from five randomly selected, permanently marked shrubs and grasses within the exclosures from each of the six species (five shrubs and one grass) at 2- to 3-week intervals. We dried and weighed all samples and sent them to Utah State University for a full suite of nutrient analysis. Although we present the data for several nutrients in Table 1, we focus here on crude protein $(\mathrm{CP})$, total digestible nutrients (TDN), metabolizable energy $(\mathrm{ME})$, and the minerals calcium $(\mathrm{Ca})$ and phosphorus $(\mathrm{P})$.

We analyzed the two-factor factorial design with 11 sampling times and six plant species (five shrubs and one grass) using the Number Cruncher Statistical System general linear models procedure to determine the differences of nutrient levels in the plant species seasonally. ${ }^{8} \mathrm{We}$ determined mean separations using a protected Fisher's Least Significant Differences procedure $(P \leq 0.05)$.

\section{Changes in Nutrient Concentration}

We found that all shrub species maintained higher nutrient levels than the crested wheatgrass throughout the sampling period including into the winter $(P<0.05)$. The crested wheatgrass provided adequate nutrition to meet the requirements of most ungulates during the earlier part of the grazing season, but declined sharply during the latter part. The shrubs also declined, but were able to maintain significantly higher amounts of nutrients.

\section{Crude Protein}

Crude protein concentration of all shrubs and crested wheatgrass grass were highest in May. Grass levels declined significantly by midsummer. The shrubs, however, maintained a higher percentage of $\mathrm{CP}$ throughout the sampling period. Fourwing saltbush provided the highest level of $\mathrm{CP}$ for all shrubs at most sampling dates (Fig. 1). Percent CP of fourwing saltbush was $27.15 \%$ in May at the beginning sampling date and steadily declined to end the sampling period (late December) at $11 \%$. Winterfat also maintained more than an adequate level of $\mathrm{CP}$ throughout the sampling period (Fig. 1). Prostrate kochia provided about average levels of CP throughout most of the spring and summer periods, but increased in CP on the November sampling date (Fig. 1). This correlates with the green-up occurring as a response to fall precipitation. Percent $\mathrm{CP}$ of crested wheatgrass decreased from $13.2 \%$ (19 May) to 5.3\% (28 June) then dropped to $3.8 \%$ in December (Fig. 1).

\section{Total Digestible Nutrients}

Levels of TDN for all shrubs species followed a similar pattern throughout the sampling period (Fig. 2). Fourwing saltbush concentration of TDN exceeded all other species from the earliest sampling date until late summer when amounts within sagebrush, winterfat, and prostrate kochia increased, while fourwing saltbush continued to decline. Levels of TDN in all shrub species exceeded that of crested wheatgrass for all sampling dates, particularly in late fall and early winter. Percent TDN in prostrate kochia increased more than the other shrubs during the fall and early winter period.

\section{Metabolizable Energy}

Fourwing saltbush began the sampling period at $2.5 \mathrm{Mcal} / \mathrm{kg}$ (1.1 Mcal/pound) and exhibited a steady and consistent decline through the sampling season, ending at $1.8 \mathrm{Mcal} / \mathrm{kg}$ (0.82 Mcal/pound; Fig. 3). The ME of all other shrub species began the season near $2.2 \mathrm{Mcal} / \mathrm{kg}(1.0 \mathrm{Mcal} /$ pound $)$ and declined steadily until early September when an increase was recorded. Prostrate kochia dropped to $1.8 \mathrm{Mcal} / \mathrm{kg}$ $(0.82 \mathrm{Mcal} /$ pound) in September and then increased to $1.9 \mathrm{Mcal} / \mathrm{kg}(0.86 \mathrm{Mcal} /$ pound $)$ in November. Big sagebrush, rabbitbrush, and winterfat also experienced similar increases after the early September sampling date. Concentration of $\mathrm{ME}$ for crested wheatgrass was significantly lower than all shrub species at all sampling dates.

\section{December Nutrient Concentrations}

Table 1 shows the nutrient concentrations of all species at the end of the sample period (December) in comparison with the nutrient requirements of a growing steer, a cow in the latter part of her lactation, a dry cow, and an elk. We chose these animals for comparison to include a variety of the common nutrient requirements of animals during the winter. Crested wheatgrass was the most insufficient in $\mathrm{CP}$ and TDN compared to the needs of the animals. It contained sufficient $\mathrm{Ca}$ and $\mathrm{P}$ and was close in providing enough $\mathrm{ME}$ (1.5 Mcal $/ \mathrm{kg} \mathrm{DM}[0.86 \mathrm{Mcal} /$ pound]). In contrast, in December, all shrubs contained sufficient $\mathrm{CP}, \mathrm{Ca}$, and $\mathrm{P}$ for all animals except rubber rabbitbrush (9\%) which contained insufficient CP for the growing steer. None of the shrubs or crested wheatgrass contained a high enough concentration of TDN in December for all animal species. However, with the exception of rubber rabbitbrush, the shrubs contained enough TDN to support the dry beef cow and came close to being sufficient for the steer and lactating cow. Winterfat and big sagebrush had $1.9 \mathrm{Mcal} / \mathrm{kg}$ dry matter (DM) ME (0.86 Mcal/pound) which was equal to or more than the requirements for all animals. Fourwing saltbush and prostrate forage kochia contained slightly less (1.8 Mcal $/ \mathrm{kg}$ DM ME [0.82 Mcal pound]). 
Table 1. Nutritional data values of five shrub and one grass species growing near Malta, Idaho, in December 1993 aligned with the nutrient requirements of various animals. Factor-level interactions between sampling date and plant species were statistically significant $(P<0.05)$ for all nutritional elements evaluated. Focal nutrients are bolded as well as nutrient concentrations that meet or surpass all animal requirements

\begin{tabular}{|c|c|c|c|c|c|c|c|c|c|c|}
\hline & $\begin{array}{l}\text { Fourwing } \\
\text { saltbush }\end{array}$ & Winterfat & $\begin{array}{l}\text { Prostrate } \\
\text { kochia }\end{array}$ & $\begin{array}{c}\text { Rubber } \\
\text { rabbit- } \\
\text { brush }\end{array}$ & $\begin{array}{c}\text { Big } \\
\text { sage- } \\
\text { brush }\end{array}$ & $\begin{array}{c}\text { Crested } \\
\text { wheat- } \\
\text { grass }\end{array}$ & $\begin{array}{l}\text { Growing } \\
\text { steer* }^{*}\end{array}$ & $\begin{array}{l}\text { Lactating } \\
\text { beef cowt }\end{array}$ & $\begin{array}{l}\text { Dry } \\
\text { beef } \\
\text { cow } \ddagger\end{array}$ & $\begin{array}{c}\text { Elk } \\
\text { mainte- } \\
\text { nance§ }\end{array}$ \\
\hline $\begin{array}{l}\% \text { Crude } \\
\text { protein }\end{array}$ & 11 & 13 & 11 & 9 & 12 & 3.8 & 11 & 7.8 & 6.9 & 8.5 \\
\hline$\%$ Calcium & 1.7 & 1.7 & 1.5 & 1.5 & 1.5 & 0.4 & 0.24 & 0.20 & 0.16 & 0.35 \\
\hline \% Phosphorus & 0.26 & 0.29 & 0.26 & 0.22 & 0.27 & 0.24 & 0.20 & 0.14 & 0.12 & 0.25 \\
\hline$\%$ Potassium & 1.0 & 0.9 & 1.0 & 1.4 & 2.2 & 1.5 & & & & \\
\hline$\%$ Magnesium & 0.28 & 0.27 & 0.31 & 0.19 & 0.21 & 0.12 & & & & \\
\hline \% Dry matter & 93 & 94 & 93 & 95 & 94 & 94 & & & & \\
\hline $\begin{array}{l}\% \text { Neutral } \\
\text { detergent } \\
\text { fiber }\end{array}$ & 55 & 55 & 54 & 48 & 33 & 75 & & & & \\
\hline $\begin{array}{l}\text { \% Modified } \\
\text { crude protein }\end{array}$ & 41 & 40 & 38 & 37 & 30 & 39 & & & & \\
\hline $\begin{array}{l}\% \text { Acid } \\
\text { detergent } \\
\text { fiber }\end{array}$ & 42 & 58 & 40 & 44 & 34 & 50 & & & & \\
\hline $\begin{array}{l}\text { \% Digestible } \\
\text { dry matter }\end{array}$ & 56 & 58 & 58 & 55 & 62 & 50 & & & & \\
\hline $\begin{array}{l}\text { \% Total } \\
\text { digestible } \\
\text { nutrient }\end{array}$ & 50 & 52 & 50 & 48 & 53 & 42 & 56 & 54 & 49 & 64 \\
\hline $\begin{array}{l}\text { Net energy } \\
\text { lactation } \|\end{array}$ & 1.1 & 1.2 & 1.1 & 1.1 & 1.2 & 0.9 & & & & \\
\hline $\begin{array}{l}\text { Metabolizable } \\
\text { energy\| }\end{array}$ & 1.8 & 1.9 & 1.8 & 1.7 & 1.9 & 1.5 & 0.9 & 1.9 & 1.8 & 1.9 \\
\hline $\begin{array}{l}\text { Net energy } \\
\text { maintenance }\end{array}$ & 1.0 & 1.0 & 1.0 & 0.9 & 1.1 & 0.7 & & & & \\
\hline $\begin{array}{l}\text { Net energy } \\
\text { gain } \|\end{array}$ & 0.42 & 0.49 & 0.42 & 0.36 & 0.52 & 0.16 & & & & \\
\hline $\begin{array}{l}\text { Relative } \\
\text { feed value }\end{array}$ & 95 & 99 & 106 & 107 & 176 & 63 & & & & \\
\hline
\end{tabular}

*250-kg (551-pound) steer gaining $1 \mathrm{~kg}\left(2.2\right.$ pound)/day. ${ }^{19}$

$+1,000$ pound beef cow in the 7 months since calving with a 20 -pound peak milk production (National Research Council requirements). ${ }^{20}$

₹1000 pound dry beef cow 9 months since calving (NRC requirements, Poland). ${ }^{20}$

$\S$ Puntenny. ${ }^{21}$

|| Mcal/kg dry matter. 


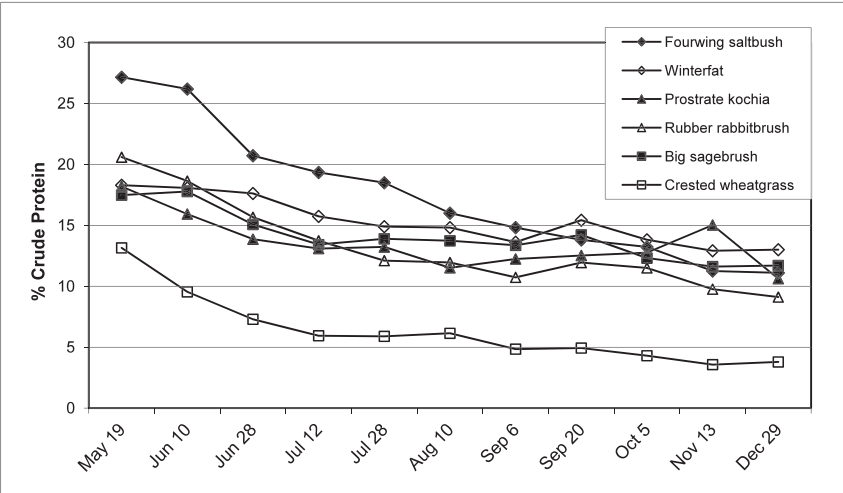

Figure 1. Decline of crude protein concentration of five shrub and one grass species planted near Malta Idaho with samples collected every 2 to 3 weeks from May to December in 1993. The species-by-date interaction was significant at $P<0.05$.

\section{Concerns With Incorporating Shrubs on Winter Pastures and Ranges}

The results of this study confirm that shrubs maintain higher levels of nutrients than crested wheatgrass, especially later in the grazing season, and can be used to reduce or eliminate the need for supplemental feed during the winter. However, a potential difficulty with shrubs and the concept of forage class mixture ${ }^{9}$ is their acceptability to livestock and wildlife. For example, although big sagebrush and rubber rabbitbrush are readily eaten by most wildlife, sheep, and goats, ${ }^{10,11}$ they are not generally palatable to cattle. In some areas, cattle might reject shrubs altogether.

However, at least in some cases, shrubs are not as unpalatable as they might seem. Schoop et al. ${ }^{12}$ found that fourwing saltbush is a very palatable shrub that is grazed by cattle in all seasons whenever it is available, but more so in winter months. Winterfat and prostrate kochia ${ }^{13}$ are readily taken by animals, including cattle, especially at the critical time when the grasses begin to dry out and lose their nutritional value. The use of shrubs

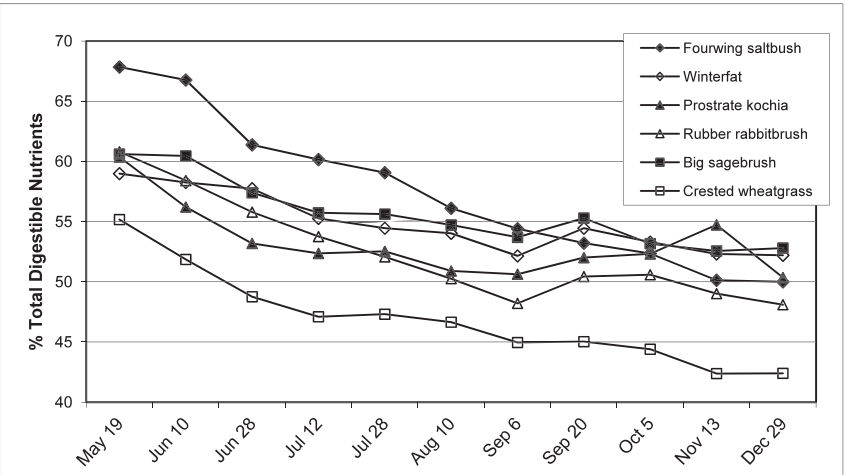

Figure 2. Decline of total digestible nutrients of five shrub and one grass species planted near Malta Idaho with samples collected every 2 to 3 weeks from May to December in 1993. The species-by-date interaction was significant at $P<0.05$.

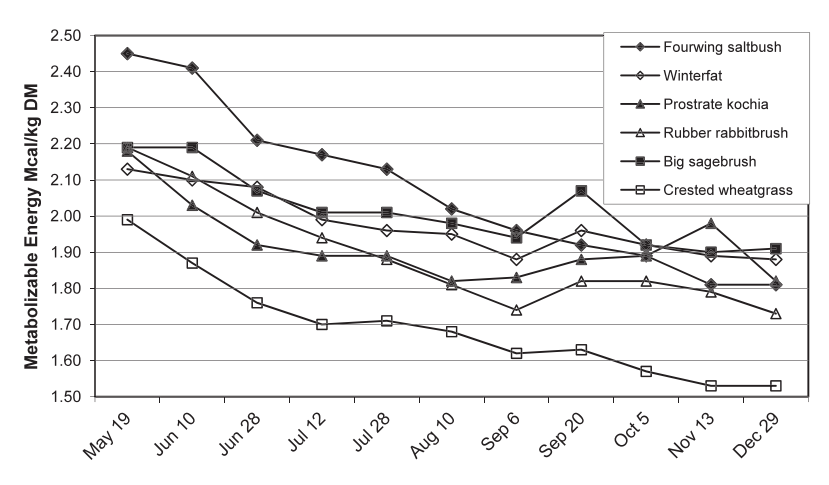

Figure 3. Decline of metabolizable energy of five shrub and one grass species planted near Malta Idaho with samples collected every 2 to 3 weeks from May to December in 1993. The species-by-date interaction was significant at $P<0.05$.

in cattle grazing could be enhanced by developing accessions that are more palatable to cattle and by modifying cattle behavior toward alternative food sources. Provenza and $\mathrm{Balph}^{14}$ suggest that diet training livestock will create more productive rangelands.

The shrubs' adaptability to the cold desert ecosystem and tolerance to grazing is also a concern. Fourwing saltbush is grazing-tolerant if allowed to establish. ${ }^{15}$ Winterfat is adapted to the intermountain area but often is so palatable that it can be grazed out of a system and thus requires some management consideration. Prostrate kochia is well-adapted to sites within the intermountain area, especially pinyonjuniper, big sagebrush, and salt-desert shrub communities. ${ }^{16}$ Big sagebrush and rabbitbrush are also hardy species well-adapted to these communities. With care and proper management shrub species can be established and maintained on rangelands.

\section{Value of Incorporating Shrubs on Winter Pastures and Ranges}

Our results indicate that the shrubs in this study are prime candidates for seeding pastures and rangelands throughout the salt desert and upland bunchgrass communities within the Great Basin. In addition to their nutrient concentrations, there are other potential benefits. Adding shrubs to crested wheatgrass compliments the ecosystem in several ways: 1 ) shrubs permit animals to maintain an adequate level of $\mathrm{CP}$ and other essential elements in their diet; ${ }^{9}$ 2) shrubs are available during periods of snow accumulation; 3) quantity of shrub growth lost to trampling is low relative to the crested wheatgrass; ${ }^{17}$ 4) shrubs provide cover for nesting, hiding, and inclement weather; and 5) shrubs can create a microenvironment favoring the establishment and increased herbage production of understory species. ${ }^{18} \mathrm{~A}$ mixture of shrubs and grasses can extend the grazing season, improve nutritional value and compliment other natural resource values by creating a more diverse ecosystem. 


\section{References}

1. Rickard, W. H., J. D. Hedlund, and R. E. Fitzner. 1977. Elk in the shrub steppe region of Washington: an authentic record. Science 196:1009-1010.

2. Young, J. A., And B. A. Sparks. 1985. Cattle in the cold desert. Logan, UT, USA: Utah State University Press. 255 p.

3. West, N. E. 1983. Great Basin-Colorado Plateau sagebrush semi-desert. In: N. E. West, [ED.]. Temperate deserts and semi-deserts. Amsterdam, The Netherlands: Elsevier Science Publishing Company. p 331-374.

4. Rogler, G. A., And R. J. Lorenz. 1983. Crested wheatgrassearly history in the United States. Journal of Range Management 36:91-93.

5. Hulet, A., B. A. Roundy, and B. Jessop. 2010. Crested wheatgrass control and native plant establishment in Utah. Rangeland Ecology \& Management 63:450-460.

6. Stevens, A. R. 1992. Establishment and disturbance of forage kochia seedlings within crested wheatgrass stands [thesis]. Provo, UT, USA: Brigham Young University. 37 p.

7. Memmott, K. L., V. J. Anderson, and S. B. Monsen. 1998. Seasonal grazing impact on cryptogamic crusts in a cold desert ecosystem. Journal of Range Management 51:547-550.

8. NCSS. 1989. Number Cruncher Statistical System. Kaysville, UT, USA: J. L. Hintze.

9. Соок, C. W. 1971. Comparative nutritive values of forbs, grasses, and shrubs. In: C. M. McKell, J. P. Blaisdell, and J. R. Goodin [EDs.]. Wildland shrubs - their biology and utilization. Ogden, UT, USA: USDA Intermountain Forest and Range Experiment Station General Technical Report INT-1, August 1972. p 303-310.

10. Welch, B. L., and J. C. Pederson. 1981. In vitro digestibility among accessions of big sagebrush by wild mule deer and its relationship to monoterpenoid content. Journal of Range Management 34:497-500.

11. Ноbbs, N. T., D. L. Baker, and R. B. Gill. 1983. Comparative nutritional ecology of montane ungulates during winter. Journal of Wildlife Management 47:1-16.

12. Schoop, M. C., R. C. Clark, W. A. Laycock, and R. M. Hansen. 1985. Cattle diets on shortgrass ranges with different amounts of fourwing saltbush. Journal of Range Management 38:443-449.

13. Monsen, S. B., J. F. Vallentine, and K. H. Hoopes. 1990. Seasonal dietary selection by beef cattle grazing mixed crested wheatgrass-forage kochia pastures. Proceedings, Western Section, American Society of Animal Science 41:300-303.
14. Provenza, F. D., And D. F. Balph. 1987. Diet training: behavioral concepts and management objectives. In: F. D. Provenza, J. T. Flinders, and E. D. McArthur [EDs.]. Proceedings of the 1985 Symposium on Plant-Herbivore Interactions. Ogden, UT, USA: USDA Intermountain Forage and Range Experiment Station General Technical Report INT222. p. 132-136.

15. Plummer A. P., D. R. Christensen, and S. B. Monsen. 1968. Restoring big game range in Utah. Salt Lake City, UT, USA: Utah State Department of Fish and Game. Publication 68-3. 183 p.

16. Stephens, R., K. R. Jorgensen, E. D. McArthur, and J. N. DAvis. 1985. 'Immigrant' forage kochia. Rangelands 7:22-23.

17. Provenza, F. D., and J. H. Richards. 1984. Interseeding crested wheatgrass ranges. Utab Science 45:73-77.

18. Monsen, S. B. 1980. Interseeding fourwing saltbush (Atriplex canescens) with crested wheatgrass (Agropyron desertorum) on southern Idaho rangelands. Society for Range Management, 33rd Annual Meeting, San Diego, CA, USA. [Abstract]

19. [NRC] National Research Council. 1984. Nutrient requirements of beef cattle. 6th revised edition. Washington, DC, USA: National Academies Press. 90 p.

20. Poland, C. 2000. NRC nutrient requirements. Fargo, ND, USA: Dickinson Research Extension Center, North Dakota State University. Extension Bulletin 74. Available at: http://www.ag.ndsu.edu/pubs/ansci/beef/eb74w.htm. Accessed 15 May 2011.

21. Puntenny, S. 1995. Health and feeding needs for Wapiti. Delta, CO, USA: Foster Mills. Available at: http://www.wapiti. net/feed.cfm. Accessed 15 May 2011.

Authors are Ecologist, USDA Forest Service, Shrub Sciences Lab, Rocky Mountain Research Station, 735 North 500 East Provo, UT 84606, USA (Memmott); and Professor of Plant and Wildife Sciences, val_anderson@byu.edu (Anderson) and Research Associate (Fugal), Brigham Young University, 275 WIDB, Provo, UT 84602, USA. Brigham Young University Skaggs Research Ranch provided the study site as well as funding. The USDA Forest Service Shrub Sciences Lab provided equipment, expertise, and assistance. 